\title{
PENGARUH PENGETAHUAN PRODUK DAN RELIGIOSITAS TERHADAP KEPUTUSAN PEMBELIAN DENGAN SIKAP SEBAGAI VARIABEL INTERVENING
}

\author{
Harini Abrilia Setyawati \\ STIE Putra Bangsa \\ harini.abrilia.setyawati@gmail.com
}

\begin{abstract}
This study aims to determine how the influence of product knowledge and religiosity on purchasing decisions through attitude as an intervening variable. The population of this research is women in Kebumen Regency. The sample in this study were 100 people. The sampling technique used is purposive sampling, with criteria for women who buy cosmetics with halal labels. Methods of collecting data with a questionnaire. Respondents' attitudes were measured using a 4-level Likert scale and the data obtained were processed by using SPSS (Statistical Product and Services Solutions) analysis for windows version 25.0. Data analysis used descriptive analysis, and statistical analysis (path analysis). The results showed that there was no significant effect of product knowledge on attitudes but there was a significant effect of product knowledge on purchasing decisions. Then religiosity affects attitudes, attitudes towards purchasing decisions.
\end{abstract}

Keywords: product knowledge, religiosity, attitudes and purchasing decisions

\section{PENDAHULUAN}

Kosmetik merupakan salah satu kebutuhan penting untuk sebagian besar wanita. Kosmetik tidak hanya peralatan untuk merias wajah. Kosmetik seperti produk perawatan tubuh atau yang biasa disebut bodycare juga digunakan para wanita untuk merawat tubuh. Atas dasar tersebut, banyak industri kosmetik terus berusaha memenuhi kebutuhan konsumen akan kosmetik dengan berbagai macam inovasi produk yang disesuaikan dengan permintaan dan kebutuhan.

Permintaan dan kebutuhan yang berbeda membuat perusahaan berlomba-lomba menciptakan produk terbaik dengan berbagai macam variasi yang disesuaikan dengan kebutuhan pasar. Perbedaan demografis membuat perusahaan kosmetik berusaha memenuhi permintaan pelanggan bahkan dengan spesifikasi khusus. Misalnya, meski sama-sama perempuan, pelanggan muslim memiliki kecenderungan untuk memilih kosmetik yang halal dibandingkan dengan pelanggan nonmuslim.

Halal bukan hanya tentang makanan, seperti yang selalu terlintas di benak orang, tetapi halal mencakup semua aspek kehidupan. Halal berasal dari frasa bahasa Arab yaitu halla, yahillu, hillan, wahalalan yang artinya boleh atau dibolehkan dengan menggunakan hukum syariah. Dalam pengertian umum, produk halal tidak boleh terkontaminasi dengan hewan yang dilarang oleh aturan Islam seperti anjing dan babi atau kontaminasi apa pun dengan alkohol. Untuk makanan itu sendiri, hewan ternak yang diperbolehkan dalam aturan Islam harus disembelih berdasarkan hukum Syariah Islam.

Kosmetik halal menjadi hal yang penting dan seiring dengan kesadaran halal pada konsumen muslim. Menurut Bodiat (2017), bagi Muslim yang konservatif tidak akan membeli produk seperti orang lain. Mereka akan melihat detail 
untuk memastikan produk tersebut halal karena kesadaran dan pengetahuan mereka tentang halal dalam kehidupan sehari-hari.

Di Indonesia, halal dan tidaknya produk diatur oleh LPPOM MUI. Kesadaran konsumen muslim tidak hanya terhadap produk makanan halal tetapi juga pada kosmetik halal. Data dari LPPOM MUI menjelaskan bahwa tahun 1994 sertifikasi halal MUI baru dimulai dari pangan. Pada tahun 2012, barulah ada produk kosmetik yang mengajukan sertifikasi. Pada tahun 2012 ada 26 produk kosmetik bersertifikat halal dari lima perusahaan. Pada tahun 2016 sudah ada 4.961 produk kosmetik bersertifikat dari 87 perusahaan. Data tersebut menjelaskan bahwa produk kosmetik yang halal semakin meningkat seiring dengan meningkatnya tingkat kesadaran muslimah dalam menginginkan produk kosmetik halal.

Pengetahuan produk penting digunakan untuk mengetahui apakah seorang calon konsumen paham mengenai barang yang akan dibelinya, apakah barang tersebut benar-benar halal, dan apakah konsumen paham di mana ia bisa memperoleh barang tersebut (Tri, 2014 dalam Rochmanto, 2014).

Latar belakang Religiositas secara juga memengaruhi keputusan pembelian konsumen. Religiositas adalah sejauh mana individu berkomitmen kepada agamanya dan dengan agama itulah tecermin sikap dan perilaku individu (Abd Rahman et al., 2015). Hal ini juga memperkuat fenomena tentang konsumen muslim dan keputusan pembelian yang tinggi pada kosmetik yang halal, di mana religiosity merupakan variabel fundamental yang kuat hingga bisa membuat para konsumen yang memeluk agama Islam menginginkan produk yang halal dengan latar belakang ajaran agama yang menuntut untuk selalu menggunakan produk halal dan menjauhi yang haram.

\section{Pengetahuan}

Menurut penelitian sebelumnya, pengetahuan memengaruhi niat melalui sikap. Oleh karena itu, peningkatan pengetahuan cenderung memengaruhi niat (Haque, Anwar, Tarofder, Ahmad, \& Sharif, 2018). Secara umum, pengetahuan mengacu pada fakta, perasaan, atau pengalaman yang diketahui oleh seseorang atau sekelompok orang; itu juga dapat didefinisikan sebagai kesadaran, kesadaran atau keakraban yang diperoleh melalui pengalaman atau pembelajaran (Abd Rahman, Asrarhaghighi, \& Ab Rahman, 2015). Pengetahuan didefinisikan sebagai keahlian dan keterampilan yang diperoleh seseorang atau sekelompok orang melalui pemahaman teoretis atau praktis dari suatu subjek (Che Ahmat et al., 2011; Sinclair, 2010) pengetahuan memiliki pengaruh terhadap niat melalui sikap. Penelitian sebelumnya mengenai pengetahuan telah membuktikan bahwa pengetahuan memiliki pengaruh positif terhadap sikap (Ahmad, Rahman, \& Rahman, 2015).

Pengetahuan berpengaruh terhadap sikap untuk memilih produk kosmetik yang halal, karena konsumen memiliki pengetahuan yang cukup untuk membedakan antara bahan yang diizinkan dan bahan yang dilarang (Mohd Suki \& Mohd Suki, 2018). memiliki pesan yang kuat kepada perusahaan kosmetik, khususnya produsen, pengecer, dan distributor produk kosmetik tentang perlunya menumbuhkan pengetahuan yang lebih baik di kalangan konsumen tentang konsumsi produk kosmetik halal.

Meskipun banyak yang telah dipelajari tentang pengaruh pengetahuan terhadap makanan, pemahaman tentang apakah pengetahuan memengaruhi sikap terhadap kosmetik halal masih jarang, ada hipotesis sebagai berikut.

H1: Pengetahuan berpengaruh terhadap sikap produk kosmetik halal. 
H3: Pengetahuan berpengaruh terhadap keputusan pembelian produk kosmetik halal.

\section{Religiositas}

Religiositas didefinisikan sebagai sejauh mana seorang individu berkomitmen pada agama yang dianutnya dan ajarannya, seperti sikap dan perilaku individu yang mencerminkan komitmen tersebut (Sungkar, 2010). Agama dapat dianggap sebagai indikator yang sangat penting dalam setiap proses pengambilan keputusan di mana hal tersebut merupakan landasan yang mengarahkan seseorang untuk berperilaku secara sah dan etis (Haque et al., 2018). Religiositas lebih berpengaruh terhadap perilaku dibandingkan dengan pengetahuan halal (Ahmad et al., 2015). Agama dapat dianggap sebagai elemen penting dalam proses pengambilan keputusan individu. Konsumen Muslim memperoleh pengetahuan yang sesuai dengan lebih memercayai informasi yang diterima dari sumber yang memenuhi syarat, yang berasal dari otoritas atau pemimpin agama yang dapat diandalkan. Namun, produk kosmetik sebagian besar diproduksi oleh manufaktur non-Muslim dan didistribusikan dari negara-negara non-Muslim. Oleh karena itu, konsumen muslim tetap meragukan kandungan bahan dalam produk kosmetik tersebut, baik yang disebut halal maupun nonhalal (Mohd Suki \& Mohd Suki, 2018).

Religiositas berpengaruh pada sikap terhadap produk kosmetik halal, yang berarti semakin banyak agama maka akan semakin meningkatkan sikap konsumen terhadap produk kosmetik yang halal. Tingkat religiositas meningkat dilihat dari ketepatan membayar zakat, aktif dalam acara keagamaan, membaca buku, menonton keagamaan di TV. Religiositas juga membangkitkan minat membeli produk kosmetik halal (Mohd Suki \& Mohd Suki, 2018).
Penelitian sebelumnya menemukan bahwa ada korelasi antara afiliasi keagamaan konsumen dan sejumlah variabel terkait konsumsi (Swimberghe, Sharma, \& Flurry, 2009). Kurangnya studi yang menyelidiki hubungan antara religiositas dan sikap terhadap produk kosmetik. Karena konsumen menjadi lebih peduli dengan status halal dari produk yang mereka konsumsi, penelitian ini menguji hubungan antara religiositas dan sikap terhadap produk kosmetik halal. Oleh karena itu, dihipotesiskan sebagai berikut.

$\mathrm{H} 2$ : Religiositas berpengaruh pada sikap terhadap produk kosmetik halal.

$\mathrm{H} 2$ : Religiositas berpengaruh terhadap keputusan pembelian produk kosmetik halal.

$\mathrm{H} 2$ : Sikap berpengaruh terhadap keputusan pembelian produk kosmetik halal.

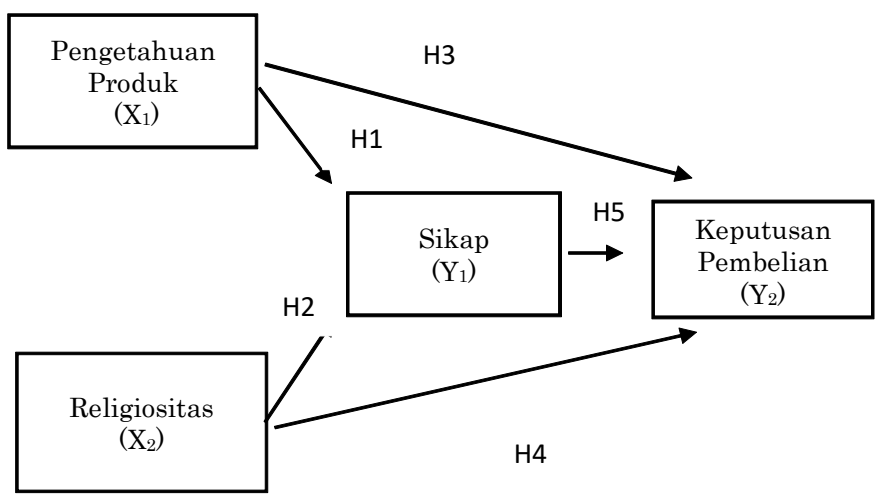

Gambar 1 Model Empiris

\section{METODOLOGI}

Populasi dalam penelitian ini adalah perempuan di Kabupaten Kebumen. Sampel dalam penelitian ini menggunakan purposive. Pertimbangan yang digunakan adalah wanita yang telah membeli dan menggunakan produk kosmetik halal. Pengukuran pengetahuan produk menggunakan Brucks (2009) yaitu diukur melalui; subjective knowledge, objective knowledge dan experienced based knowledge. Kemudian variabel religiositas menggunakan Glock dalam Rahmat (2013) dengan indica- 
tor; keyakinan, peribadatan, penghayatan, pengetahuan dan pengamalan. Pengukuran sikap menggunakan cognitive component, affective component dan behavioral component. Sedangkan keputusan pembelian menggunakan kemantapan pada sebuah produk, kebiasaan dalam membeli produk, memberikan rekomendasi kepada orang lain dan melakukan pembelian ulang.

\section{HASIL DAN PEMBAHASAN}

Responden berdasarkan usia dapat dijelaskan bahwa usia $>18$ tahun sebanyak 9 responden atau 9\%, responden dengan usia 18-20 tahun sebanyak 42 orang atau 42\%, usia 21-23 tahun sebanyak 28 orang atau $28 \%$ dan usia $>23$ tahun sebanyak 21 orang atau $21 \%$.

Hasil uji validitas menunjukkan bahwa rhitung lebih besar dari rtabel $(0,1975)$ dengan nilai signifikansi sebesar $0,0000<0,05$ sehingga semua item pertanyaan yang dipakai pada variabel label halal dinyatakan valid (sah).

Berdasarkan hasil uji reliabilitas dapat dijelaskan bahwa seluruh variabel yang dipakai dalam penelitian ini dinyatakan reliabel (andal) karena nilai $\mathrm{r}$ alpha $<0,60$.

\section{Uji Asumsi Klasik}

\section{Uji Multikolinieritas}

Uji multikolinieritas dimaksudkan untuk mengetahui apakah dalam persamaan regresi ditemukan adanya korelasi antar-variabel terikat. Model regresi yang baik seharusnya tidak terjadi korelasi antar variabel terikat. Menurut Ghozali (2009) untuk mendeteksi ada atau tidaknya multikolinieritas dalam model regresi dapat dideteksi dengan melihat besaran VIF dan tolerance di atas 0,1 merupakan model persamaan yang tidak terdapat multikolinieritas.
Tabel 1 Uji Multikolinearitas I

\begin{tabular}{|l|c|c|}
\hline \multirow{2}{*}{\multicolumn{1}{|c|}{ Model }} & \multicolumn{2}{c|}{ Collinearity Statistics } \\
\cline { 2 - 3 } & Tolerance & VIF \\
\hline (Constant) & & \\
\hline Pengetahuan & 0.979 & 1.021 \\
\hline Religiositas & 0.979 & 1.021 \\
\hline
\end{tabular}

Berdasarkan tabel coefficient di atas dapat dijelaskan bahwa pada bagian collinearity statistic menunjukkan angka VIF tidak lebih besar dari 10 dan tolerance lebih dari 0,10. Berdasarkan hasil tersebut dapat diketahui bahwa model regresi substruktural I dan II tidak terdapat multikolinieritas, sehingga model dapat dipakai.

Tabel 2 Uji Multikolinearitas I

\begin{tabular}{|l|c|c|}
\hline \multirow{2}{*}{\multicolumn{1}{|c|}{ Model }} & \multicolumn{2}{c|}{ Collinearity Statistics } \\
\cline { 2 - 3 } & Tolerance & VIF \\
\hline (Constant) & & \\
\hline Pengetahuan & 0.974 & 1.026 \\
\hline Religiositas & 0.898 & 1.113 \\
\hline Sikap & 0.907 & 1.103 \\
\hline
\end{tabular}

\section{Uji Normalitas}

Uji normalitas bertujuan untuk menguji apakah data yang akan digunakan dalam model regresi

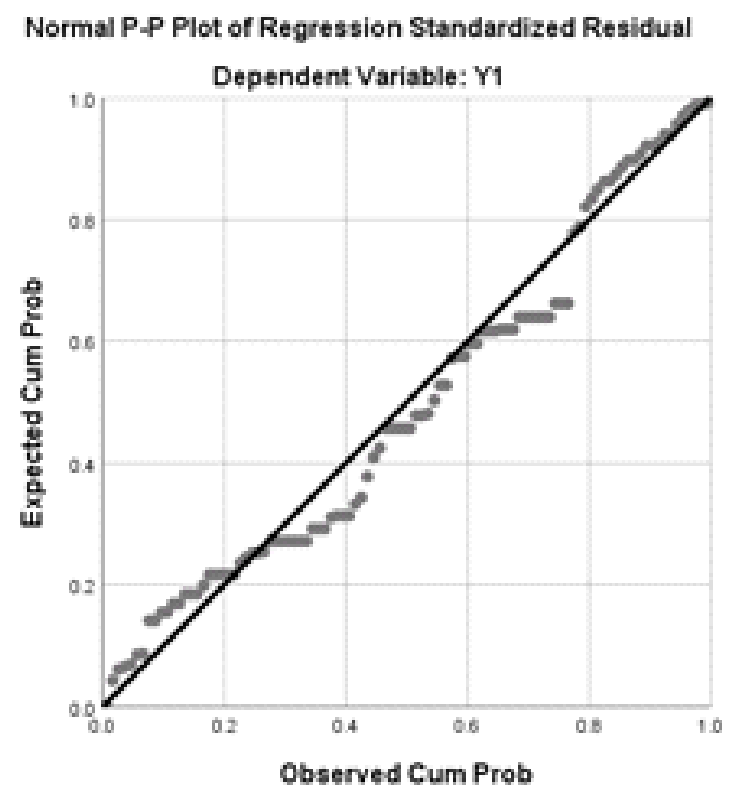

Gambar 2 Uji Normalitas I 
berdistribusi normal atau tidak (Ghozali, 2009). Metode grafik normal plot dengan kriteria bahwa jika data menyebar di atas garis diagonal dan mengikuti arah garis diagonal, maka model regresi tersebut memenuhi asumsi normalitas.

Berdasarkan Gambar 2 terlihat bahwa data menyebar di sekitar garis diagonal. Maka model memenuhi asumsi normalitas.

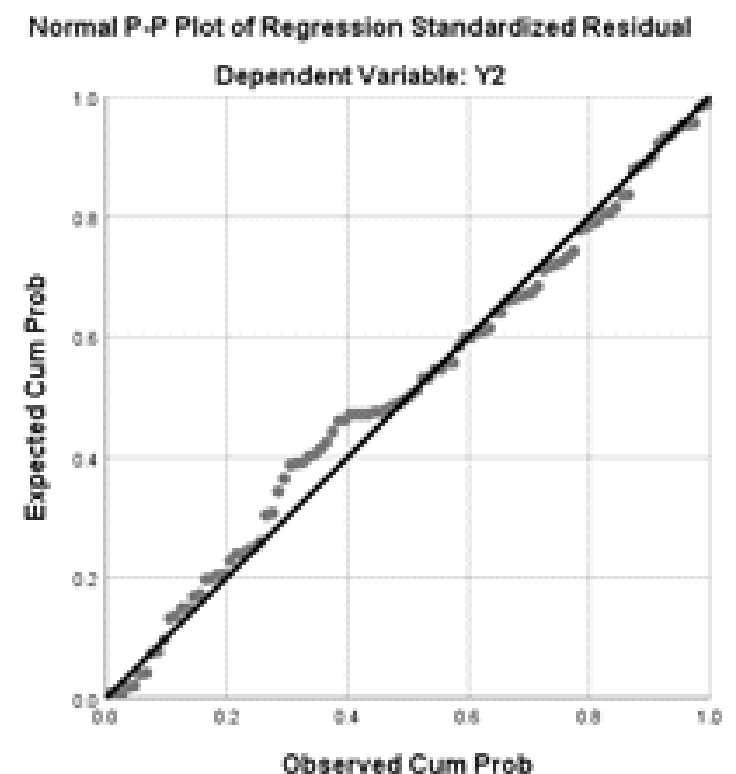

Gambar 3 Uji Normalitas I

\section{Uji Heteroskedastisitas}

Uji heterokedastisitas ini dimaksudkan untuk menguji apakah dalam model regresi terjadi ketidaksamaan varian yang residual dari satu pengamatan ke pengamatan yang lain. Adanya heterokedastisitas dapat dideteksi dengan melihat ada tidaknya pola tertentu pada grafik, di mana sumbu $\mathrm{X}$ adalah $\mathrm{Y}$ yang diprediksi dan $\mathrm{X}$ adalah residual (Y prediksi- $Y$ sesungguhnya) yang telah du studentized. Model regresi yang dapat digunakan adalah model yang memenuhi yaitu tidak terdapat pola yang jelas serta titik-titik pada grafik menyebar di atas dan di bawah angka 0 (nol) pada sumbu Y. Hasil uji heterokedastisitas adalah sebagai berikut.

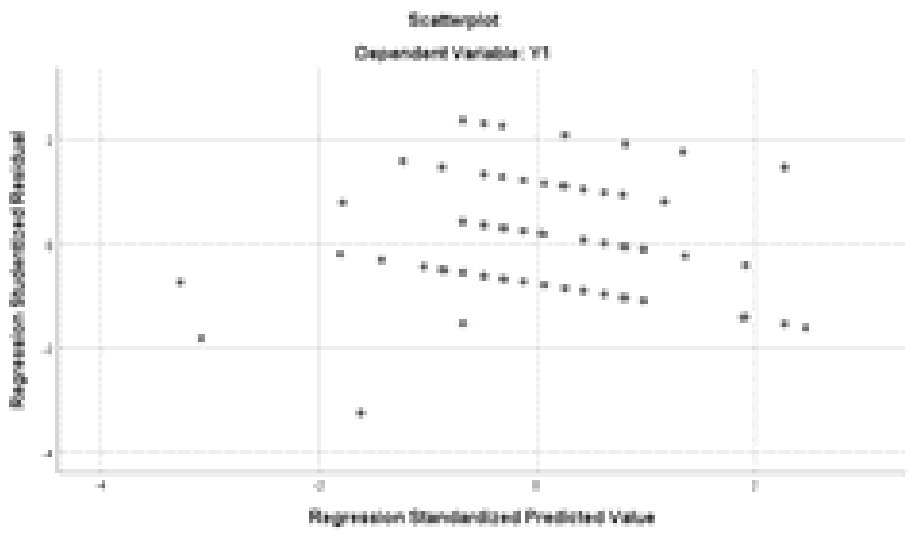

Gambar 4 Hasil Uji Heteroskedastisitas I

Berdasarkan gambar grafik heterokedastisitas di atas menunjukkan bahwa tidak ada pola tertentu, seperti titik-titik (poin) yang membentuk suatu pola tertentu yang teratur (bergelombang, melebar, kemudian menyempit) dan tidak ada pola yang jelas maka dapat disimpulkan model regresi dalam penelitian ini tidak terjadi heterokedastisitas.

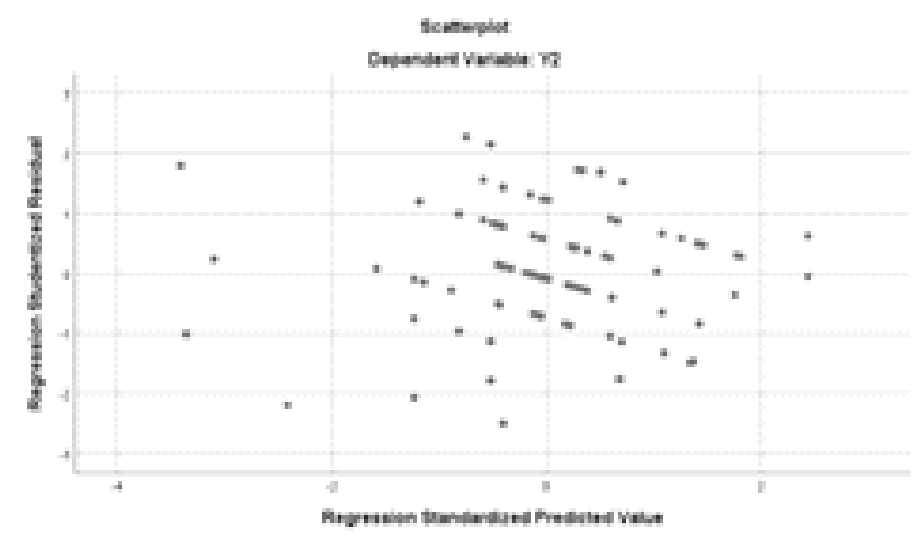

Gambar 5 Hasil Uji Heteroskedastisitas II

\section{Uji Hipotesis}

Pengujian ini dilakukan untuk mengetahui pengaruh secara parsial atau sendiri-sendiri antara variabel bebas (pengetahuan produk dan religiositas) terhadap variabel terikat (keputusan pembelian) dengan sikap sebagai variabel intervening. 


\section{Pengetahuan Produk dan Sikap}

Hasil perhitungan yang diperoleh dari angka thitung sebesar $0.690<$ ttabel sebesar 1,985 maka pengetahuan produk tidak berpengaruh signifikan terhadap sikap sehingga H1 ditolak.

\section{Religiositas dan Sikap}

Hasil perhitungan yang diperoleh dari angka thitung sebesar 2,950> ttabel sebesar 1,985 maka religiositas berpengaruh signifikan terhadap sikap.

\section{Pengetahuan Produk dan Keputusan Pembelian}

Hasil perhitungan yang diperoleh dari angka thitung sebesar 2.426>ttabel sebesar 1,985 maka pengetahuan produk berpengaruh signifikan terhadap keputusan pembelian sehingga $\mathrm{H} 1$ diterima.

\section{Religiositas dan Keputusan Pembelian}

Hasil perhitungan yang diperoleh dari ang$\mathrm{ka}$ thitung sebesar 2,893> ttabel sebesar 1,985 maka religiositas berpengaruh signifikan terhadap keputusan pembelian.

\section{Sikap dan Keputusan Pembelian}

Hasil perhitungan yang diperoleh dari angka thitung sebesar $1,927<$ ttabel sebesar 1,985 maka sikap tidak berpengaruh signifikan terhadap keputusan pembelian.

\section{KESIMPULAN}

Pengujian hipotesis pertama dilakukan untuk mengetahui bagaimana pengaruh pengetahuan produk terhadap sikap. Hasil penelitian menunjukkan bahwa pengetahuan produk tidak berpengaruh terhadap sikap. penelitian ini bertolak belakang dengan penelitian terdahulu yang dilakukan oleh Hamzah (2017).

Pengujian hipotesis kedua dilakukan untuk mengetahui bagaimana pengaruh religiositas terhadap sikap. Hasil penelitian menunjukkan religiositas berpengaruh terhadap sikap. penelitian ini sejalan dengan penelitian terdahulu yang dilakukan oleh Indah dan Dewi (2017).

Pengujian hipotesis ketiga dilakukan untuk mengetahui bagaimana pengaruh pengetahuan produk terhadap keputusan pembelian. Hasil penelitian menunjukkan pengetahuan produk berpengaruh terhadap keputusan pembelian. Penelitian ini sejalan dengan penelitian terdahulu yang dilakukan oleh Siddiq (2015).

Pengujian hipotesis keempat dilakukan untuk mengetahui bagaimana pengaruh religiositas terhadap keputusan pembelian. Hasil penelitian menunjukkan religiositas berpengaruh terhadap keputusan pembelian. Penelitian ini sejalan dengan penelitian terdahulu yang dilakukan oleh, Wahyudin, dan Wulandari (2011).

Pengujian hipotesis kelima dilakukan untuk mengetahui bagaimana pengaruh sikap terhadap keputusan pembelian. Hasil penelitian menunjukkan sikap berpengaruh terhadap keputusan pembelian. Penelitian ini sejalan dengan penelitian terdahulu yang dilakukan oleh Wahyuni (2017).

\section{DAFTAR RUJUKAN}

Abd Rahman, A., Asrarhaghighi, E., \& Ab Rahman, S. (2015). Consumers and Halal cosmetic products: knowledge, religiosity, attitude and intention. Journal of Islamic Marketing, 6(1), 148-163.

Ancok, Djamaludin \& Fuad Nashori Suroso. (1995). Psikologi Islam Solusi Islam Atas Problem-Problem Psikologi. Yogyakarta: Pustaka Pelajar. 
Andisti, Miftah A. dan Ritandiyono. (2008). Religiositas dan Perilaku Seks Bebas pada Dewasa Awal. Jurnal Psikologi. Vol. 1, No. 2. Hlm. 170-176.

Anggelina, J. \& Japarianto, E. (2014). Analisis Pengaruh Sikap, Subjective Norm, dan Perceived Behavioral Control terhadap Purchase Intention Pelanggan Sogo Department Store di Tunjungan Plaza Surabaya. Jurnal Strategi Pemasaran, 2(1), 1-7.

Angipora, Marinus. (2002). Dasar-Dasar Pemasaran. Jakarta: PT Raja Grafindo Persada

Azwar. S. (2010). Sikap Manusia Teori dan Pengukurannya. Yogyakarta: Pustaka Pelajar.

Ghozali, Imam. (2006). Aplikasi Analisis Multivariate dengan Program SPSS. Semarang: Badan Penerbit Universitas Diponegoro.

Golnaz, dkk. (2009). Non Muslim's Awareness of Halal Principles and Related Food Product in Malaysia. International Food Research Journal, 17, pp. 667-674.

J. Paul Peter \& Jerry C. Olson. 2005. Consumer Behaviour, Perilaku Konsumen dan Strategi Pemasaran Edisi 4 Jilid 2. Jakarta: Penerbit Erlangga.

Kotler, Philip \& Kevin Lane Keller. (1995). Manajemen Pemasaran. Jakarta: Penerbit Erlangga.

Kotler, Philip \& Kevin Lane Keller. 2007. Manajemen Pemasaran, Edisi-12. Jakarta: PT Indeks.

Kotler, Philip \& Kevin Lane Keller. (2009). Manajemen Pemasaran. Jakarta: Penerbit Erlangga.

Kotler, Philip. (2000). Manajemen Penjualan. Jakarta: Erlangga

Kuncoro, Mudrajat. (2009). Metode Riset untuk Bisnis dan Ekonomi. Jakarta: Erlangga.

Nazir, Moch. 2003. Metode Penelitian. Jakarta: Salemba Empat.
Ping Liang, Ying et al. (2009). Relationship between Consumer Information Exposure, Produk Knowledge, and Impulse Buying Behavior: An empirical Analysis. International Journal of Management. Poole: Sep 2009. Vol. 25, Iss. 3: pp. 418, 14 pgs.

Purnama, Tata Septayuda. 2011. Hubungan Aspek Religiositas dan Aspek Dukungan Sosial terhadap Konsep Diri Selebriti di Kelompok Pengajian Orbit Jakarta. Tesis Universitas Diponegoro.

Rangkuti, Ramadhan. 2010. Pengaruh Labelisasi Halal terhadap Keputusan Pembelian Produk Makanan dalam Kemasan (Snack Merek Chitato). Skripsi Fakultas Hukum Universitas Sumatera Utara.

Robbins S.P. \& Judge. (2007). Perilaku Organisasi. Jakarta: Salemba Empat.

Rochmanto, B. Al. (2014). Pengarub Pengetahuan Produk dan Norma Religius terhadap Sikap Konsumen dalam Niat Mengonsumsi Produk Makanan dan Minuman Halal (Studi Kasus di Kota Semarang). Skripsi Fakultas Ekonomika dan Bisnis Universitas Diponegoro.

Sarwono, Jonathan. (2006). Metode Penelitian Kuantitatif dan Kualitatif. Yogyakarta: Graha Ilmu.

Simamora, B. (2008). Panduan Riset Perilaku Konsumen. Jakarta: PT Gramedia Pustaka Utama.

Sudarsono. (2008). Kenakalan Remaja. Jakarta: PT Rineka Cipta.

Sugiyono. (2010). Metode Penelitian Bisnis. Bandung: Alfabeta.

Suliyanto. (2011). Ekonometrika Terapan: Teori dan Aplikasi dengan SPSS. Yogyakarta: Andi.

Suryani, Tatik. (2008). Perilaku Konsumen Implikasi pada Strategi Pemasaran. Yogyakarta: Graha Ilmu. 
Sutoyo, Anwar. (2009). Bimbingan dan Konseling Islami Teori \& Praktik. Semarang: CV Widya Karya Semarang.

Tjiptono, Fandy. (1997). Strategi Pemasaran, Edisi 2, Yogyakarta: Penerbit Andi.

Waluyo, P. \& Pamungkas, A. (2003). Analisis Perilaku Brand Switching Konsumen dalam Pembelian produk Handphone di Semarang (Artikel), 94 halaman.
Widiyanta, Ari. (2005). Sikap terhadap Lingkungan dan Religiositas. Jurnal Pemikiran dan Penelitian Psikologi, Vol. 1, No. 2, Hlm. 80.

Windartatik. (2013). Pengaruh Label Halal MUI dan Brand Image terhadap Minat Membeli Produk Kosmetik Wardah. Skripsi. Semarang: Institut Agama Islam Negeri Walisongo. 